\title{
The Digester Modification for Biogas Production from Palm Oil Mill Effluent by Batch System
}

\author{
Martha Aznury ${ }^{1, *}$, Jaksen M. Amin ${ }^{1}$, Abu $\operatorname{Hasan}^{1}$, and Triadi Utomo ${ }^{1}$ \\ ${ }^{1}$ Department of Chemical Engineering, Politeknik Negeri Sriwijaya, Palembang \\ Jl. Srijaya Negara Bukit Besar,Palembang 30139, Indonesia
}

\begin{abstract}
The purpose of this research is to determine the optimum production of biogas produced from the tuncated pyramid-shaped modification digester equipment on sedimentation tank and shaped beams on the tank fermentation batch. Pyramid-shaped sedimentation tank aiming for optimal deposition process, While the fermentation tank with beam-shaped used to produce biogas that is optimal. The raw material used is Palm Oil Mill Effluent. In the early stages of process is carried out the sedimentation in the first digester tank at a flow rate of 6 liters/minute and then observing the time stayed for 24 hours. POME flowed into the second digester tank to run into fermentation process by adding active microbial seed to produce biogas. After fermentation is complete, streamed to third digester tank to experience water treatment stage before being released into the environment. COD content test value obtained after the processing of $100 \mathrm{mg} / \mathrm{l}$, while the BOD value is $30.9 \mathrm{mg} / \mathrm{l}$. The percentage of methane gas obtained from starter concentration of $30 \%$, ie $9.82 \% \mathrm{~mol}$ for fermentation time of 10 days, while the fermentation period of 20 days is $15.8 \mathrm{~mol} \%$. The production of methane gas obtained for the optimum fermentation period of 30 days ie $33.19 \%$ mol. For days 31 through 40, the production of biogas run into highs and caused due to the substrate in the digester began to run out and most of the substrate has not been fermented.
\end{abstract}

\section{Background}

The rapid development of the palm oil industry sector has resulted in other impacts. The process of crude palm oil products $(\mathrm{CPO})$ produced solid waste and liquid waste. Liquid waste from industrial of palm oil is palm oil mill effluent (POME). POME is estimated around 63 million ton/year in Indonesia [1].

In the palm oil industry, POME will be processed in a processing pond with an open pond system. Although the pool system is economical, it requires a wider, timeconsuming and direct-release of $\mathrm{CH}_{4}$ into the atmosphere from the breakdown of organic matter occurring in anaerobic ponds. Referring to this condition, modified digester equipment is made.

The modification of the digester was carried out on a change in the shape of previous research that has been done in the past year. According to a final report written by Sari (2015) about comparison of sedimentation in a beam-shaped and a truncated pyramid-shaped [2]. The result of efficiency between beam and truncated-pyramid that were slower compared to the truncated pyramid digester.

According to a previous report, $7.3564 \% \mathrm{~mol} \mathrm{CH} 4$ with $30 \%$ stater and 4 days for fermentation in beamshaped digester [3]. The other design was a trucanted.pyramid-shaped that with $30 \%$ stater and 4 days fermentation had $6.439 \%$ mol $\mathrm{CH} 4$. So the design of the beam-shaped digester had been proven that the fermentation process is better than the design with truncated-pyramid digester.

Based on this, the authors conducted a study of the process of wastewater treatment of POME by modifying the digester with trucated pyramid-shaped for sedimentation. The digester for fermentation is a beamshaped. This design modification is expected to be applicable for industrial palm oil treatment in the potential of POME for capture of biogas. The modified digester design tool is one of the more effective and efficient ways in terms of place, time, and processing costs

\section{Methodology}

\subsection{Raw material}

Raw material is Palm Oil Mill Effluent (POME) from PT Minangan Ogan Tbk. Inoculum was get from manure and aclimitation with POME since 1 month before used on biogas production.

\subsection{Modification digester}

In the design of digester tools consists of several tools that are important components to support the POME for wastewater treatment. The design has trucated pyramid

Corresponding author: martha_aznury@polsri.ac.id 
for sedimentation tank (tank A) and beam-shapeds (tank $\mathrm{B}$ and $\mathrm{C}$ for fermentation dan collection tanks). Digester also have some supporting components such as centrifugal pump, flowmeter, tedlar bag, swan neck and vacuum pump. The modification of digester shown in Figure 1

\subsection{Analytical}

Analyzed POME before and after fermentation was used by the American Public Health Association [4]. Gas was analyzed by using using a gas chromatograph (GC8A, Shimadzu, Kyoto).

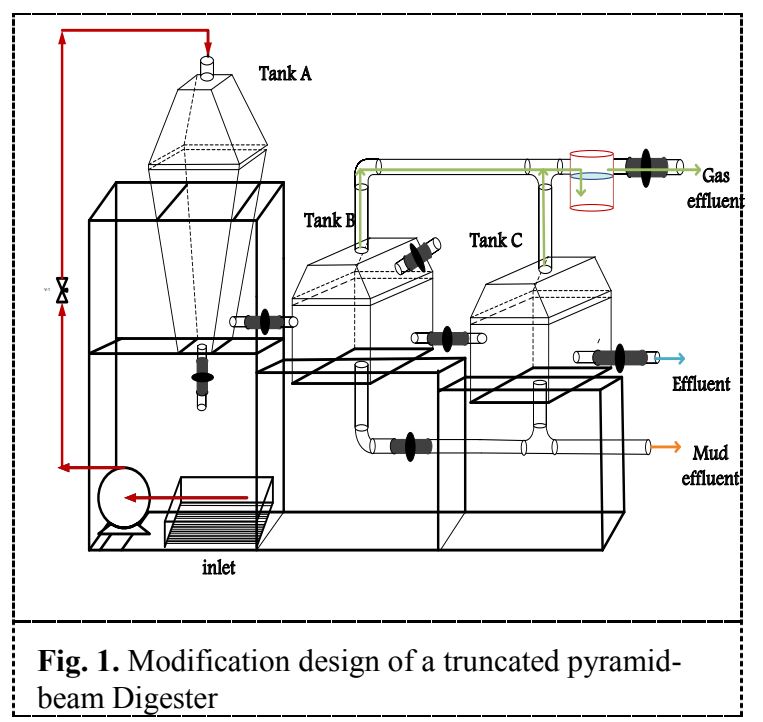

POME is pumped into tank A for sedimentation process for 24 hours for the sedimentation process. Then, from tank A will be directly piped into the second tank B for the fermentation process for 1 month and catch gas in capture bag. Tank $\mathrm{C}$ was filled after fermentation process for collection before transfer to river bank or for felitizer process.

\section{Results and discuss}

\subsection{POME after processing}

POME using modified digester, the product can be obtained in the form of water and sludge (sludge). Before the water obtained from the processing at the digester dibuangke the water receiving body must first know the chemical oxygen demand (COD) and biological oxygen demand (BOD) because it could not pass the predetermined quality standard to prevent adverse effects on the environment. After analysis, it can be known that COD and BOD water content obtained from the results of this study are as follows in Table 1 .
Table 1. Result of POME after Processing

\begin{tabular}{cc}
\hline Parameter & After 40 days Processing \\
\hline COD & $100 \mathrm{mg} /$ liter \\
BOD & $30.9 \mathrm{mg} /$ liter \\
TDS & $151 \mathrm{mg} /$ liter \\
TSS & $6200 \mathrm{mg} /$ liter \\
\hline
\end{tabular}

Chemical oxygen demand (COD)

Biological oxygen demand (BOD)

Total dissolved solids (TDS)

Total suspended solids (TSS

The result of COD is $100 \mathrm{mg} /$ liter where the value of COD is much lower when compared with Fahlevi (2015) with 4 days fermentation had a COD value of 784 $\mathrm{mg} / \mathrm{liter}$. From the data value of COD it can be seen that the COD value is determined based on the type of POME itself which means that the COD value of each palm oil liquid waste vary according to the source of the POME and the fermentation time greatly influences the reduced COD content. While for the value BOD after 40 days of fermentation is $30.9 \mathrm{mg} /$ liter which is still much lower than that of previous research has BOD 100 $\mathrm{mg} /$ liter [3].

In this research, the results of COD, BOD and TSS content analysis in POME after anaerobic fermentation process for 40 days has met the standard quality standard for which has been established based on the governor regulation of South Sumatra No. 8 of 2012 on the quality standard of liquid waste for the palm oil industry. POME could not directly be discharged into the river or water source dikarana kan still have other contents that have not meet the standard quality standards such as TSS reached $6200 \mathrm{mg} /$ liter, where the content is still too high compared to quality standards by the government of 250 $\mathrm{mg} / \mathrm{liter}$.

\subsection{Sedimentation Process}

The optimum sedimentation process for separating water and sludge from treatment of POME in pellet-shaped digester tool can be determined based on residence time and flow rate by looking at the result of previous research done that is using flow rate $6 \mathrm{~L} / \mathrm{m}$ which can achieve sedimentation efficiency of $15.6 \%$ with the observed deposition period that is at $1,3,6,12$, and 24 hours [2].

In this research, there is one idea to optimally treat POME by creating a tool that represents the modeling system in waste treatment ponds in the palm oil industry, which is expected to provide more benefits in treating waste. The principle of processing done by sedimentation and fermentation process, in the hope that the absence of result from waste treatment is thrown away. The relationship between residence time to water volume and sludge at a flow rate of 6 liters/min can be seen in Figure 2. 


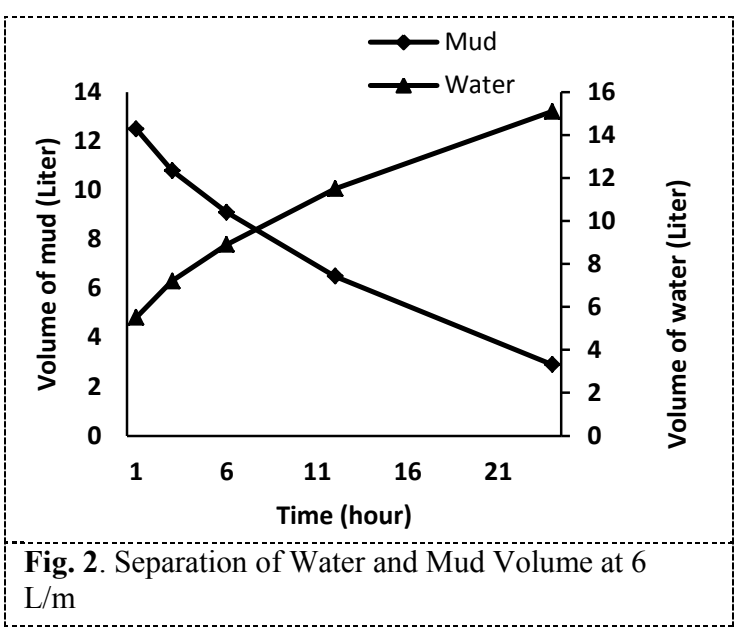

Figure 2 shown of separation between mud and water. At 1 hour, volume of mud are at 12.5 liters of the total feed volume of 18 liters. Until 24 hours decreased the volume of sludge on the pyramid-shaped digester reaches 2,9 liters. While the volume of water at 1 hour is 5,5 liters and continues to increase until the residence time of 24 hours is 15,1 liters.

This is because the sedimentation process that occurs in the digester takes place well during the residence time, where the longer the residence time the mud will settle completely and solidify on the base of the digester, causing more water to separate from the mud. The residence time is directly proportional to the flow rate, so the faster the flow rate will be the faster the time to stay. The longer the residence time, then the volume of water from the pyramid-shaped digester will be constant because the mud has settled completely [3].

\subsection{Biogas production}

POME which has been treated with a sedimentation process for 24 hours with a flow rate of 6 liters/minute in tank A, where the treatment is based on Sari research (2015) to obtain the separation of water and sludge with optimum efficiency.

Biogas is clean and renewable energy that can be an alternative to conventional energy sources that can cause problems for the environment and increase the rate of energy depletion in a long time. This biogas formation process requires a special installation called a digester, its function is that anaerobic reshuffle can take place well. The process of organically changing anaerobic material consists of four stages of the process of hydrolysis, acidogenesis, acetogenesis and methanogenesis. Therefore, this research treats POME to reduce the harmful chemical compounds of POME by utilizing the product of the processing of sludge and biogas (methane gas) by using pellet-shaped digester. The graph of biogas measurement results can be seen in Figure 3.

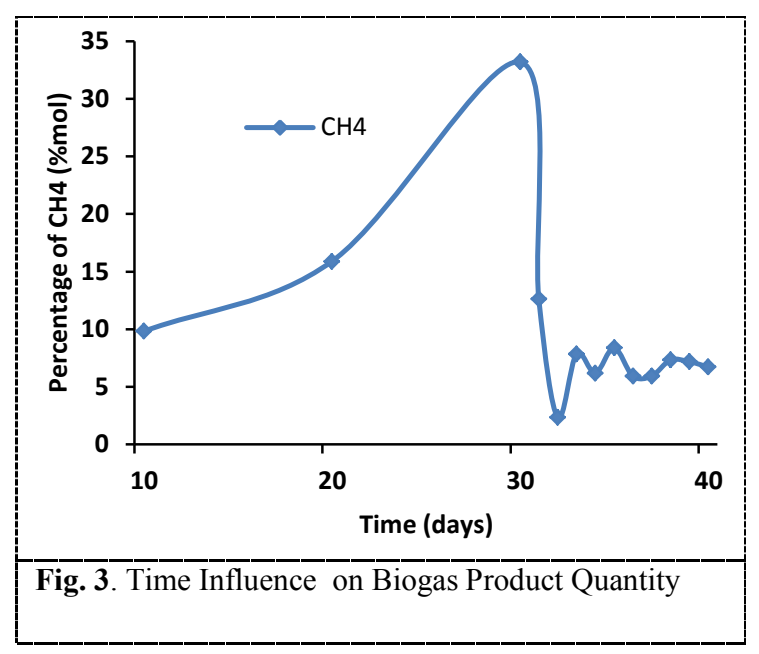

Figure 3 can be observed the effect of fermentation time on biogas produced. At the time of fermentation for 10 days, 20 days and 30 days can be seen that the quantity of biogas produced increased significantly so it can be seen that the bacteria grow and develop very well. The volume of gas increases with increasing fermentation time. The longer the fermentation time is the increased activity of microorganisms to use the substrate so that this will affect the resulting product [5]. At day 30 is the peak of biogas production of 33.1 mol\%, it indicates that the substrate is maximally converted completely into biogas. When the number of bacterial populations increases, bacterial activity produces methane gas is also increased so as to produce methane gas with greater composition. In its growth phase, every living creature needs sufficient nutrients and supporting environmental conditions for the growth process, including bacteria [6].

Biogas production decreased in days 31 and 32 to $12.6 \mathrm{~mol} \%$ and $2.3 \mathrm{~mol} \%$, it shows that the fermentation process does not have enough substrate in the digester to be converted into biogas resulting in decreased biogas production. At the time of long fermentation will be less biogas produced due to reduced substrate which is a nutrient for microorganisms [5]. The graph of biogas production on the 33rd day has increased again. This shows that microorganisms do not work maximally in substrate remodeling. Biogas production after the 34th to 40th day has up and down of trend. This indicates that the substrate has not been completely overhauled and there are some that have not been overhauled. The graph shows that the biogas fermentation time can be extended until there is not enough substrate available in the digester so that the graph of biogas production after the 40th day will decrease and eventually no biogas formation occurs.

Biogas production in this research achieved optimal result on 30th day that yield $33.1 \%$ mole of $\mathrm{CH} 4$ gas which can be from fermentation process with $30: 70 \%$ substrate concentration. The production of biogas above is much bigger compared to previous research with the same substrate concentration obtained only $7.3564 \%$ mole of $\mathrm{CH} 4$ gas at 4 day fermentation time [7]. This is because in the research Saputri with fermentation within 4 days is not enough to remodel the substrate in the 
digester optimally. Fermentation time gives a significant difference to gas production, where fermentation time has a direct effect on biogas production [8]. The effect of fermentation on biogas production is due to the content of POME which contains lots of protein and high fat and takes several days to experience the process of fermentation.

\subsection{Effect of oxygen on Biogas production}

The process of biogas formation is done anaerobically. Bacteria break down organic matter into biogas and organic fertilizer. The process of weathering this organic material is done by microorganisms in the anaerobic fermentation process [9]. Biogas is a flammable gas produced from anaerobic processes at low temperatures and without oxygen [10]. Methaneforming bacteria are bacteria that do not require free oxygen in their metabolism, even the presence of free oxygen can be toxic or affect the bacterial metabolism [11]. The effect of oxygen on biogas production can be seen in Figure 4:

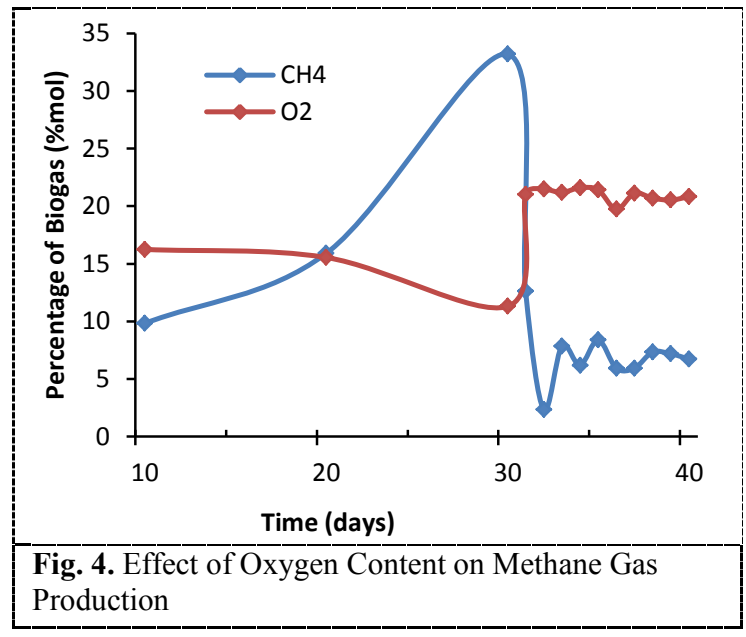

From Figure 4, the oxygen content on the 30th day is at the lowest position of $12.6 \mathrm{~mol} \%$. In this condition, methane gas production at highest condition compared to other day that is $33.1 \%$. While on the 31 st day oxygen content rose to $21 \mathrm{~mole} \%$ which made the methane gas content decreased by $11.3 \%$ mole. Thus, it can be analyzed that the oxygen content can have an effect on the determination of $\mathrm{CH} 4$ or methane gas. The higher the oxygen content the less likely the formation of $\mathrm{CH} 4$ gas.

The amount of oxygen compounds contained in the sample due to environmental factors and the reaction of bacteria in the input composition of raw materials and starter that produce side compounds or byproducts in the form of oxygen gas. High levels of oxygen in biogas greatly affect the formation of methane compounds. This is because bacteria decomposer-forming methane compounds are anaerobic or do not require oxygen. If there is a content in the fermentation process will cause the bacteria to die and will not form a methane compound [12].

\subsection{Comparison with previous research on biogas production}

Biogas production is obtained from the fermentation process of POME in reactor, where the fermentation system used is batch process. The batch process is fermented by incorporating the media and starter simultaneously into the bioreactor and the product taking is done at the end of the fermentation. Comparison of biogas production results from previous researchers can be seen in Table 2:

Table 2. Comparison of Biogas Production Results with Previous Research

\begin{tabular}{|c|c|c|c|c|}
\hline $\begin{array}{l}\text { Forms } \\
\text { Digester }\end{array}$ & $\begin{array}{l}\% \text { vol } \\
\text { strater }\end{array}$ & $\begin{array}{l}\text { Ferm.t } \\
\text { ime } \\
\text { (days) }\end{array}$ & $\begin{array}{c}\% \mathrm{~mol} \\
\mathrm{CH}_{4}\end{array}$ & Ref \\
\hline Beam & $10 \%$ & 4 & 1.3811 & $\begin{array}{c}\text { Saputri, } \\
2015\end{array}$ \\
\hline Pyramid & $10 \%$ & 4 & 1.7972 & $\begin{array}{c}\text { Fahlevi, } \\
2015\end{array}$ \\
\hline Beam & $20 \%$ & 4 & 2.0607 & $\begin{array}{c}\text { Saputri, } \\
2015\end{array}$ \\
\hline Pytamid & $20 \%$ & 4 & 1.4938 & $\begin{array}{c}\text { Fahlevi, } \\
2015\end{array}$ \\
\hline Beam & $30 \%$ & 4 & 7.3564 & $\begin{array}{c}\text { Saputri, } \\
2015\end{array}$ \\
\hline Pyramid & $30 \%$ & 4 & 6.439 & $\begin{array}{c}\text { Fahlevi, } \\
2015\end{array}$ \\
\hline $\begin{array}{l}\text { Modification } \\
\text { of pyramid } \\
\text { and beam }\end{array}$ & $30 \%$ & 30 & 33.199 & $\begin{array}{c}\text { This } \\
\text { Research, } \\
2016\end{array}$ \\
\hline
\end{tabular}

From Table 2, it can be seen that previous study produced $\mathrm{CH} 4$ optimally at $30 \%$ volume of starter in 4 days fermentation time, where Fahlevi yield was $6.439 \%$ mole $\mathrm{CH} 4$ by using pine digester while $\mathrm{CH} 4$ The resulting Saputri is $7.3564 \%$ mole $\mathrm{CH} 4[3,5]$. So from the data above, the form digester also affect the process of biogas formation. The beam-shaped digester produces more biogas than the pyramid-shaped diets. But the pellet-shaped digester is more efficient in the sedimentation process than the beam digester.

The biogas production result from previous research is still far below the optimum result of modified digester with \% mole $\mathrm{CH} 4$ which is $33.199 \%$ mole with fermentation time for 30 days $[3,5]$. Then it can be analyzed that with the process of sedimentation and optimum fermentation process made digester modification tool can produce a more optimal biogas product. In addition, the fermentation time also affects the production of biogas where the longer the fermentation time the more biogas produced. Biogas production is affected by fermentation time because the time of fermentation is directly related to the amount of time required to pass through the methane generation stages of hydrolysis, acetogenesis and methanogenesis. 


\section{Conclusion}

From the results of research on modification of pyramidshaped digester for sedimentation and block-shaped stage in the fermentation stage in the wastewater treatment of palm oil industry, it can be concluded:

1. The result of analysis in determining COD and BOD of POME after processing in this study contained a small pollutant load compared to the standard quality standard that has been determined based on Governor Regulation of South Sumatera no. 8 of 2012 About the Standard of Liquid Waste for Oil Palm Industry namely:

2. The percentage of biogas production on the 10th, 20th and 30th day was $9.8 \%, 15.9 \%$ and $33.1 \%$ mole of $\mathrm{CH} 4$, while on the 40th day it was $6.73 \%$. Then the production of biogas with batch system in the long fermentation time will decrease due to the substrate which starts to run out.

3. The optimum biogas production obtained from the digester modifier was produced on day 30 of $33.1 \%$ mole $\mathrm{CH} 4$

The authors would like to acknowledge the financial suport of Penelitian Stategis Nasional, Directorate General of Higher Education provides funding research project grants. NOMOR SPPK: 050/SP211/LT/DRPM /IV/2017. Also, authors acknowledge for PT. Perkebunan Mitra Ogan was a suport of POME.

\section{References}

1. [BPS] Badan Pusat Statistik, Data Luas Lahan Sawit, Produksi, serta Ekspor CPO 20092015,[doawnload 5 april 2016], 2016

2. Sari, Octa Endang, Perbandingan Design Alat Sedimentasi yang Berbentuk Balok dan Limas pada Pengolahan Air Limbah Industri Minyak Kelapa Sawit, Thesis of Politeknik Negeri Sriwijaya. Palembang, 2015)

3. Fahlevi, M Reza.. Pengaruh Laju Alir Terhadap Waktu Tinggal Pada Digester Berbentuk Limas Secara Batch Dalam Mengolah Air Limbah Industri Kelapa Sawit Menjadi Biogas, Thesis of Politeknik Negeri Sriwijaya (2015)

4. American Public Health Association (APHA), Standard Methods for the examination of Water and Wastewater, 19th Ed. (Washington, D.C., 1995)

5. Suryani, Y., Journal of Asian Scientific Research 12, 789-797 (2013)

6. Budiyanto. A., K.. Nutrisi Mikroba, Esensi Dasar untuk Kehidupan Mikroba. froam http://zaifbio. wordpress.com/category/mikrobiolog, [doawnload at 12 June 2016], 2009

7. Saputri, Hardina Apri, Pengaruh Persentase Volume Starter Dan Waktu Fermentasi Pada POME Terhadap Kuantitas Biogas Menggunakan Digester Balok Sistem Batch, Thesis of Politeknik Negeri Sriwijaya (2015)

8. Mujdalipah, Siti, S. Dohong, A. Suryani, and A.Fitria,, Pengaruh Waktu Fermentasi terhadap
Produksi Biogas Menggunakan Digester Dua Tahap pada Berbagai Konsentrasi Palm Oil Mill Effluent dan Lumpur Aktif, Thesis of Universitas Pendidikan Indonesia (2014)

9. Polprasert, C., Organic Waste Recycling (John Willey and Sons, Chicester, 1980)

10. Agustine, Restiyana, Produksi Biogas dari Palm Oil Mill Effluent (POME) dengan Penambahan Kotoran Sapi Potong sebagai Aktivator, Thesis of Institut Pertanian Bogor (2011)

11. Deublein, D. and Steinhauster, A., Biogas from Waste and Renewabe Resources (WILEY-VCH Verlag GmbH \& Co. KGaA, Weinheim, Berlin 2008)

12. Noresta, Febrina. Jecika Yavia Nadiaty, dan M. Faizal, Jurnal Teknik Kimia 19, 1, 2013 